\title{
NUMERICAL EVALUATION OF THE SHEAR BEHAVIOR OF A METAL SHEAR KEY USED IN JOINING PRECAST CONCRETE SEGMENTAL BRIDGE GIRDERS WITHOUT EPOXY
}

\author{
Heru Purnomo ${ }^{1 *}$, Rosi Nursani ${ }^{1}$, Sekar Mentari $^{1}$, Sjahril A. Rahim ${ }^{1}$, Elly Tjahjono ${ }^{1}$ \\ ${ }^{1}$ Department of Civil Engineering, Faculty of Engineering, Universitas Indonesia, Kampus UI Depok, \\ Depok 16424, Indonesia
}

(Received: January 2017/ Revised: June 2017 / Accepted: November 2017)

\begin{abstract}
The shear key is an important part of a precast segmental concrete bridge. Aside from its function of contributing to the distribution of shear force from one concrete segment to another, it helps to join precast concrete segments to become a complete bridge structure and provide continuity of movement for vehicles and pedestrian traffic. This numerical study discusses the behavior of a full-scale shear key connection without epoxy joining two concrete blocks representing segmental precast concrete at which two external forces load the blocks. Ferro Casting Ductile (FCD) is used as the metal shear key material where the shear key consists of two parts, a male and a female shear key. Numerical simulation is conducted using the ANSYS academic package, with nonlinear analysis implemented accordingly. The appropriate constitutive materials in relation to the numerical program, both for concrete and FCD, are taken from the appropriate literature. Two criteria are employed in the study; failure of the concrete block and yielding of the shear key that follows the von Mises criterion. Shear key connection system capacity is evaluated by applying different magnitudes of horizontal force. The validation of two numerical simulation studies is conducted by two experimental programs that cover laboratory experimentation of full-scale shear keys connecting two concrete blocks. The numerical and experimental results produce an almost similar relation of shear stress at the male shear key and vertical displacements of the upper block relative to the lower concrete block. Finally, a contour of shear key shear stress as a function of the different magnitudes of equivalent prestressing and different quality of concrete compressive strength is proposed.
\end{abstract}

Keywords: Experimentation; Ferro casting ductile; Male and female shear keys; Numerical study; Shear stress-vertical displacement relation

\section{INTRODUCTION}

Precast concrete beam bridge decks have been constructed for a long time and serve as a complete bridge structure to provide continuity of movement for vehicles and pedestrian traffic. Ease of use, rapid erection ability, the elimination of falsework and the bringing to site of factory-quality consistencies are well-known advantages of this construction method. The most common precast concrete girders in Indonesia are I and U girders. Prior to the advent of segmental construction, concrete bridges were often made by placing several pre-stressed concrete girders side by side parallel to the longitudinal axis of the concrete bridge.

However, when applying this method, the length of the concrete girders becomes limited to the

\footnotetext{
*Corresponding author's email: herupur@eng.ui.ac.id, Tel: +62-21-7270029, Fax: +62-21-7270028
}

Permalink/DOI: https://doi.org/10.14716/ijtech.v8i6.711 
available truck transport capacity. Concrete girders in segments allow for longer spans of bridge construction to be achieved at the same time as eliminating associated transportation problems. Precast segmental bridge construction requires match casting and dimensional precision (PTI, 1978). Precision is achieved by casting each segment against the end face of the preceding one and then erecting the segments in the same order in which they were cast. The placement of a shear key between two faces of concrete girder segments, either with or without epoxy resin jointing material, can facilitate erection and allow precision to be achieved as required. Aside from prestressing at both extremities of the girder, the shear key and epoxy will also contribute to the strength of the girder segments joint. Shear keys are studied since the segmental construction method was first introduced many decades ago. Buyukozturk et al. (1990) studied flat and keyed joints as a function of prestressing force and epoxy addition. Buyukozturk et al. stated that the behavior of the dry keyed joints depends on the level of confining pressure. At lower levels of confinement, a crack appears at the root of the key accompanied by slippage in the joint, leading to a large decrease in stiffness and discontinuity in deformation. In general, although cracking occurs in advance of final failure, beginning at the bottom corner of the key, the final failure is brittle and sudden. Higher strength and stiffness of the dry keyed joints were found by increasing the level of confining pressure. Besides their single keyed joint study, Zhou et al. (2005) also looked at a various combination of keyed joints. They found that the identical normalized shear strength of 3-keyed joints was always less than that of 1-keyed joints. The failure modes of concrete keyed joints from different studies show a similar pattern. A diagonal crack initially occurs in the bottom part of the joint surface. At the second stage of loading, intensive multiple cracking or multiple diagonal cracks occur at a shear key zone. At the maximum load, the cracks at the root of the joint separate the female key from the male part (Yang et al., 2013). The Japanese standard (JSCE, 2004) suggests the use of Ferro Casting Ductile (FCD) 450 as a material for metal shear keys. FCD has better characteristics than other types of cast iron. This study discusses the behavior of a full-scale shear key joint without epoxy joining two concrete blocks that represent segmental precast concrete at which two external forces load the blocks. After validating the numerical model with two experimental results, a simulation is then conducted with different magnitudes of equivalent prestressing versus different concrete quality in terms of its compressive strength. The shear capacity of the joint is defined by either the tensile failure of the concrete block or the yielding of the shear key. The shear capacity of an FCD 450 shear key to different conditions of prestressing and concrete quality will be obtained. A better understanding of shear key behavior will enable bridge engineers to better address bridge operational problems such as overloading (Rifai et al., 2015).

\section{METHODOLOGY}

The numerical model is developed based on the shear key experimental test set-up as shown in Figure 1. The experimental set-up itself was constructed according to that used by a number of previous researchers in the concrete keyed joint (Koseki \& Breen, 1983; Buyukozturk et al., 1990; Issa \& Abdalla, 2007). As presented in Figure 1, two concrete blocks representing segmental precast concrete were placed in a test frame. Appropriate concrete strengths for the two blocks were produced to resemble precast segmental bridge concrete strength. At midheight, the two concrete blocks are joined by an FCD 450 metal shear key. Two external forces load the blocks. To enable the shear test, a vertical monotonic force exerted by a hydraulic jack loads the upper concrete block. The second force represents an equivalent prestressing force given by another hydraulic jack placed horizontally centered to the shear key location. Two load cells are placed at the interface between the hydraulic jack and an upper concrete block, while four digital gauges are placed vertically near the gap between the two concrete blocks, and another digital gauge is placed horizontally at the left edge of the upper concrete block. The 
two load cells record the forces exerted by the two hydraulic jacks, with all four of the digital gauges giving the displacement of the upper concrete block relative to the lower concrete block. Another horizontal gauge is placed to discover the horizontal displacement of the upper concrete block.
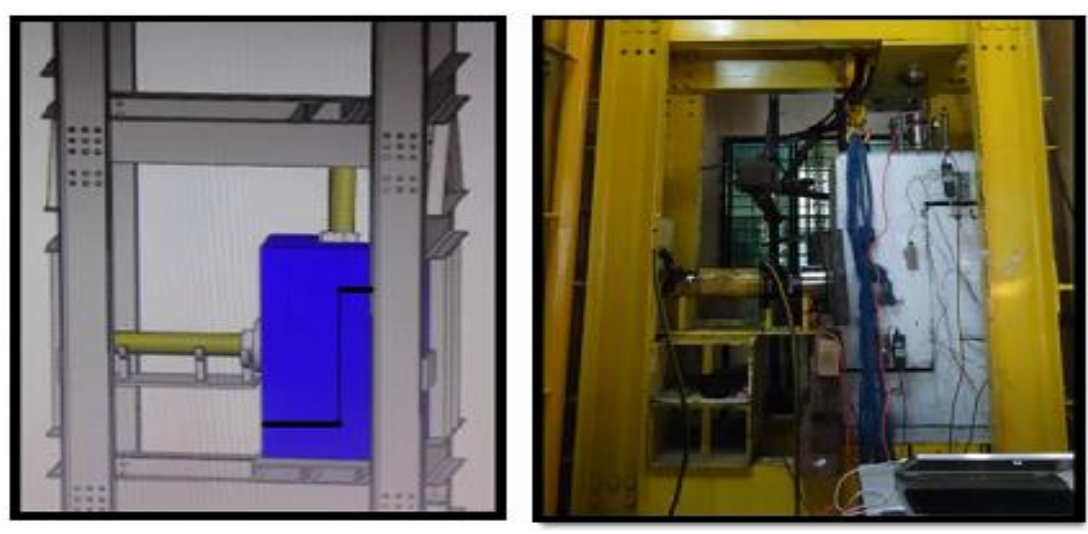

Figure 1 Experimental test set-up

\subsection{Material for Experimentation}

The metal shear key is made from FCD 450, while the two concrete blocks are made from dry mix concrete with 28 days' mean compressive strength at about $45 \mathrm{MPa}$, which resulted in three $15 \mathrm{~cm}$ diameter cylindrical concrete specimens tested by a compression machine. The geometry of the shear key is similar to the steel shear key produced by PT. Wijaya Karya Beton. Figure 2 presents the side view of the metal shear key comprising the male and female shear key parts. The male shear key is represented by the light brown color, while the female shear key is the gray-green shiny color. The dimensions of the two concrete blocks are shown in Figure 3 . The shear key that joins the two concrete blocks is placed at the mid-height of the two concrete blocks. The male shear key is located at the upper concrete block while the female shear key is placed at the lower concrete block, as shown in Figure 3. The two concrete blocks were sufficiently reinforced to resist their own weight while the blocks were lifted into the test frame. There are two horizontal $2 \mathrm{~cm}$ gaps between the two blocks at the upper and lower sides of the lower concrete block. There is no gap at the vertical interface of the two concrete blocks.

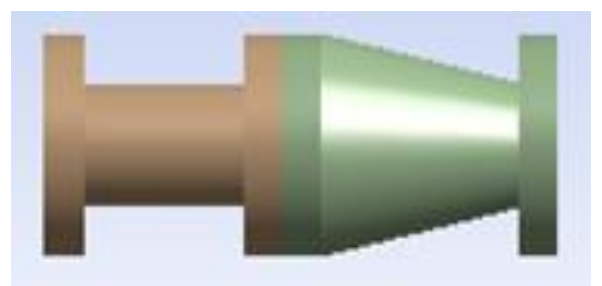

Figure 2 Male and female components of the shear key 


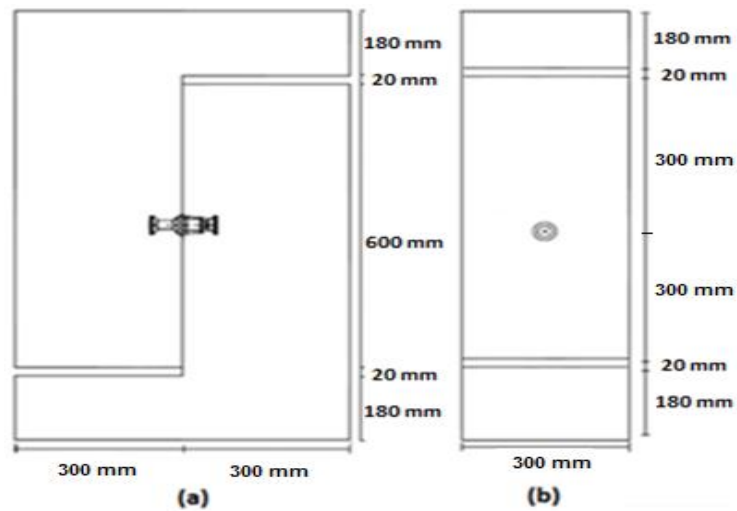

Figure 3 Concrete blocks and shear key: (a) Front view; (b) Section

\subsection{Numerical Simulation}

The appropriate constitutive material relations for the numerical program for both concrete and FCD were taken from the appropriate literature. The concrete compressive stress-strain relation model is taken from Reddiar (2009), the tensile stress-strain relation model is obtained from $\mathrm{Hu}$ H.T. et al. (2004), and the shear stress-displacement model is taken from Kaneko et al. (2004). The FCD compression and tensile stress-strain relation model is taken from Minnebo et al. (2006) and the shear stress-strain relation is obtained from Dahlberg et al. (2014). The tensile failure of a concrete block is assumed to occur when principal stresses in excess of $0.45 \mathrm{Vf}$ 'c (RSNI-T-12-2004) occur over an area in the outward direction from the male shear key location, or when there is yielding of the shear key using the von Mises criterion (Dowling, 2007). The capacity of the shear key connection system is evaluated by applying different magnitudes of horizontal force and varying the quality of the concrete blocks that represent the compressive strength. Table 1 presents the analysis cases covering the permutations of the concrete compressive strength $(\mathrm{C})$ and the magnitude of the horizontal prestressing force $(\mathrm{P})$. The support condition of the lower concrete block and the area of loading in the numerical simulation is represented in Figure 4, where no translation is possible at the support as shown in Figure $4 \mathrm{a}$ and external forces are applied as pressure over the area of loading, as displayed in Figures $4 \mathrm{~b}$ and $4 \mathrm{c}$.

Table 1 Parametric simulation

\begin{tabular}{lccccr}
\hline Variation & $\begin{array}{c}\text { Compressive } \\
\text { Strength of } \\
\text { Concrete }(\mathrm{MPa})\end{array}$ & $\begin{array}{c}\text { Prestressing } \\
(\mathrm{MPa})\end{array}$ & Variation & $\begin{array}{c}\text { Compressive } \\
\text { Strength of } \\
\text { Concrete }(\mathrm{MPa})\end{array}$ & $\begin{array}{c}\text { Prestressing } \\
(\mathrm{MPa})\end{array}$ \\
\hline C40P1 & 40 & 0.345 & $\mathrm{C} 50 \mathrm{P} 3$ & 50 & 0.69 \\
C40P2 & 40 & 0.5175 & $\mathrm{C} 50 \mathrm{P} 4$ & 50 & 0.8625 \\
C40P3 & 40 & 0.69 & C45P1 & 55 & 0.345 \\
C40P4 & 40 & 0.8625 & C55P2 & 55 & 0.5175 \\
C45P1 & 45 & 0.345 & C55P3 & 55 & 0.69 \\
C45P2 & 45 & 0.5175 & C55P4 & 55 & 0.8625 \\
C45P3 & 45 & 0.69 & C60P1 & 60 & 0.345 \\
C45P4 & 45 & 0.8625 & C60P2 & 60 & 0.5175 \\
C50P1 & 50 & 0.345 & C60P3 & 60 & 0.69 \\
C50P2 & 50 & 0.5175 & C60P4 & 60 & 0.8625 \\
\hline
\end{tabular}




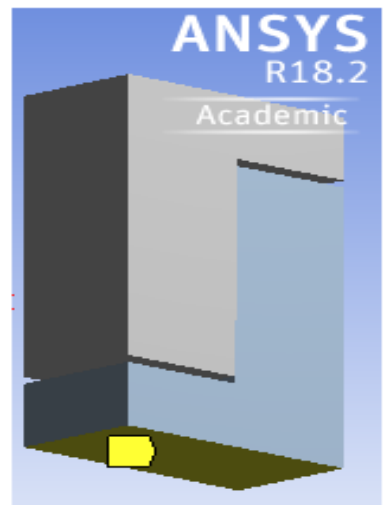

(a)

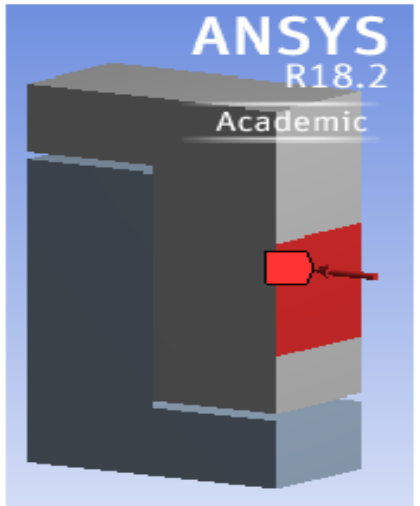

(b)

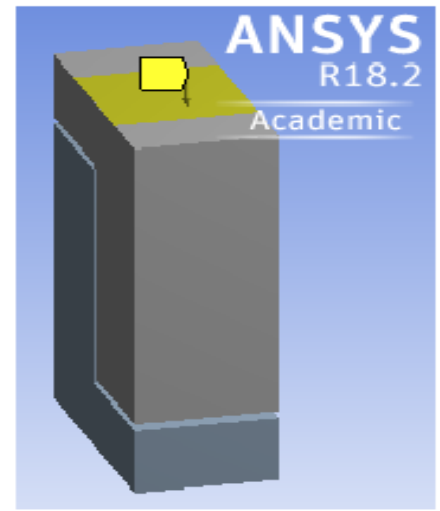

(c)

Figure 4 Support condition and loading area: (a) Support; (b) Area of horizontal loading; (c) Area of vertical loading

SOLID186 element is used in the 3D simulation, while surface-to-surface contact elements TARGE170 and CONTA174 are used to model the contact between elements. Bonded contact is assumed for contact between the upper concrete block and the male shear key, the male shear key and the female shear key, and the female shear key and the lower concrete block. Frictional contact is implemented at the interface of the two concrete blocks, where a friction coefficient of 0.6 is applied (Buyukozturk et al., 1990). In the numerical study, the Poisson ratio of FCD material is taken as 0.28 , while that of concrete is 0.2 .

\section{RESULTS AND DISCUSSION}

\subsection{Stress Observation at Male Shear Key}

Figure 5 shows the difference of von Mises stress at the male shear key calculated numerically for two cases: C45P1, as shown in Figure 5a, and C45P2, as shown in Figure 5b, when the horizontal gap between the two concrete blocks closes.

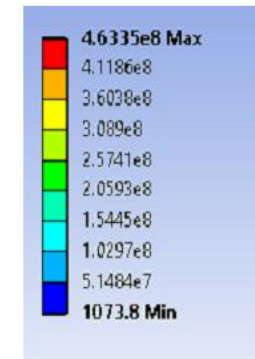

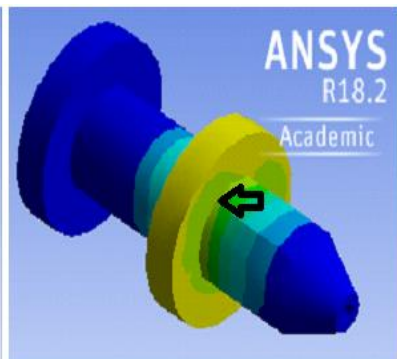

(a)

Figure 5 von Mises stress contour at two shear key cases: (a) C45P1; (b) C45P2

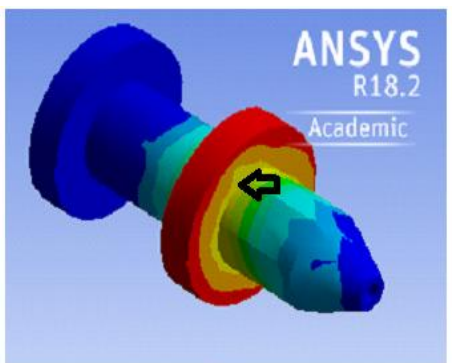

(b)

In the case of C45P2, the stresses at the butt of the male shear key already exceed the von Mises envelope, while those for $\mathrm{C} 45 \mathrm{P} 1$ remain within the von Mises envelope.

\subsection{Validation of the Numerical and Experimental Results}

Validation of the numerical approach will be carried out by comparing the numerical and experimental results. The validation will be based on three parameters: the shear stressdisplacement curves, the final deformation of the male shear key, and the final concrete damage pattern near to the male and female shear keys. The location of the observed shear stress is in the middle of the male shear key cross-section. Figures 6, 7, and 8 present a comparison of the three parameters between the numerical and experimental results. Shear stress evolution is a 
function of normal stress increase in the male shear key. Figures $6 \mathrm{a}$ and $6 \mathrm{~b}$ indicate that when one point at the lower side of the male shear key begins to yield, then shear stress will drop but then later, when hardening takes place, shear stress will rise until the ultimate tensile stress is reached at the level of normal stress. Even though there are small differences between the experimental and numerical results for case C45P2, as shown in Figure 6b, its shear stressvertical displacement behavior is almost similar in shape.
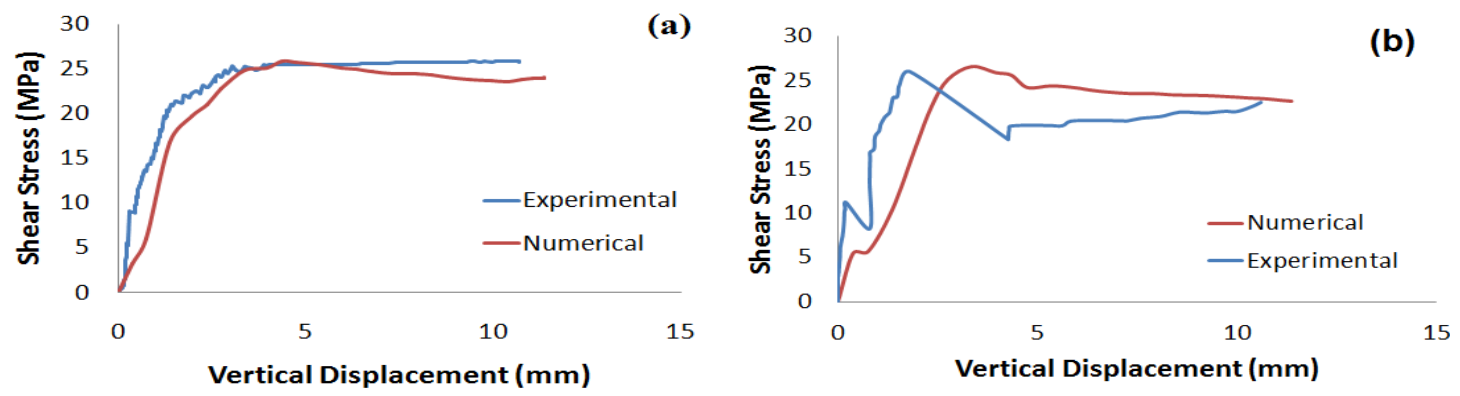

Figure 6 Shear stress-vertical displacement comparison between experimental and numerical approach for 2 cases: (a) C45P1 (b) C45P2

The final deformation shape of both results from the experimental (see Figure 7a) and numerical (see Figure 7b) point of view is almost similar, with only a slight difference of deformation angle between the two results. The final damage concrete pattern of both results is also similar. At the nearby male shear key, cracks occur at the proximity of the male shear key and then spread or propagate diagonally toward the outer side of the upper concrete block (see Figure $8 a$ ), while only concrete spallings occur at the lower side near to the female shear key at the lower concrete block (see Figure 8b).

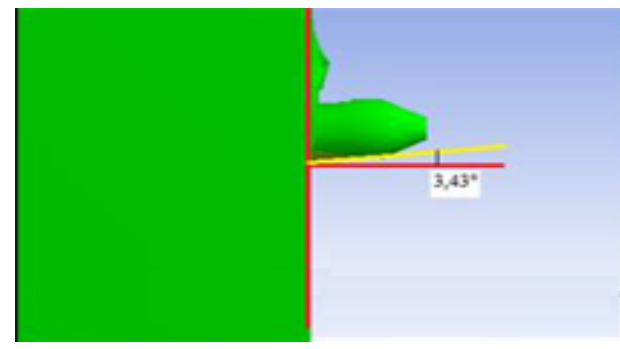

(a)

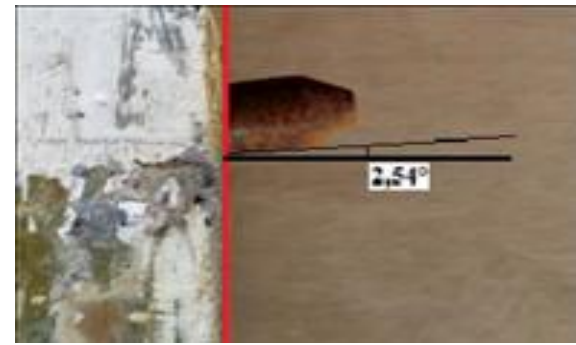

(b)

Figure 7 Comparison of male shear key final deformation for case C45P1: (a) Numerical;

(b) Experimental

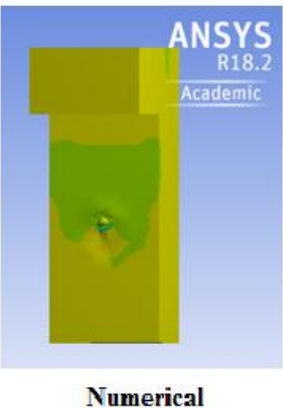

(a)

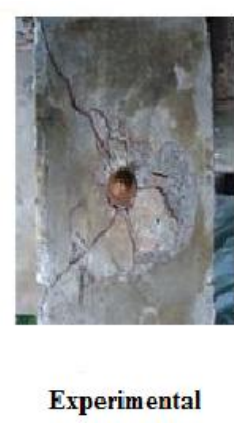

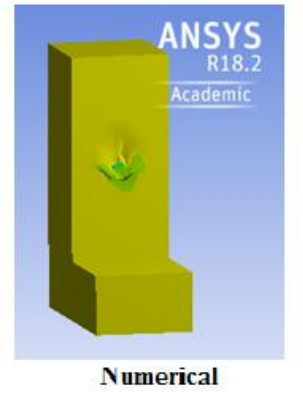

(b)

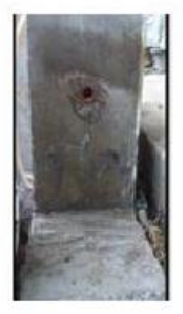

Experimental

Figure 8 Comparison of final crack pattern results from the numerical and experimental approaches for case C45P2: (a) Nearby male shear key; (b) Nearby female shear key 


\subsection{Simulation of Different Magnitudes of Prestressing and Concrete Quality}

Based on the similarities shown between the three parameters in the above comparison, this study continues with a numerical simulation for different magnitudes of prestressing and concrete quality, represented by the concrete compressive strength, as stipulated in Table 1. In general, for the same magnitude of prestressing and for a given same value of vertical displacement of concrete block, the male and female shear keys embedded in a better quality of concrete, but in a dry joint condition, will resist a higher magnitude of vertical external load, as shown in Figure 9. This means that a higher axle load of vehicle could be resisted by the same shear key embedded in a better quality of concrete (see Figures 9a, 9b, 9c, and 9d). For a lower quality of concrete, the shear key will be rapidly deformed as the concrete sustains damage adjacent to the male shear key.

For the same concrete compressive strength, higher prestressing will increase the concrete's shear capacities against cracking. For instance, in case C45P1, concrete near to the male shear key begins to show micro cracks at $28.6 \mathrm{kN}$ external vertical loading, while the male shear key will experience yield at $134.2 \mathrm{kN}$. Meanwhile, C45P2, with a higher horizontal load, shows that concrete near to the male shear key begins to show a micro crack at $38.2 \mathrm{kN}$ vertical loading and the male shear key begins to yield at a vertical loading of $157.8 \mathrm{kN}$. In this relation, the existence of a higher horizontal load decelerates the propagation of a crack in the upper concrete block and the development of yield in the male shear key.
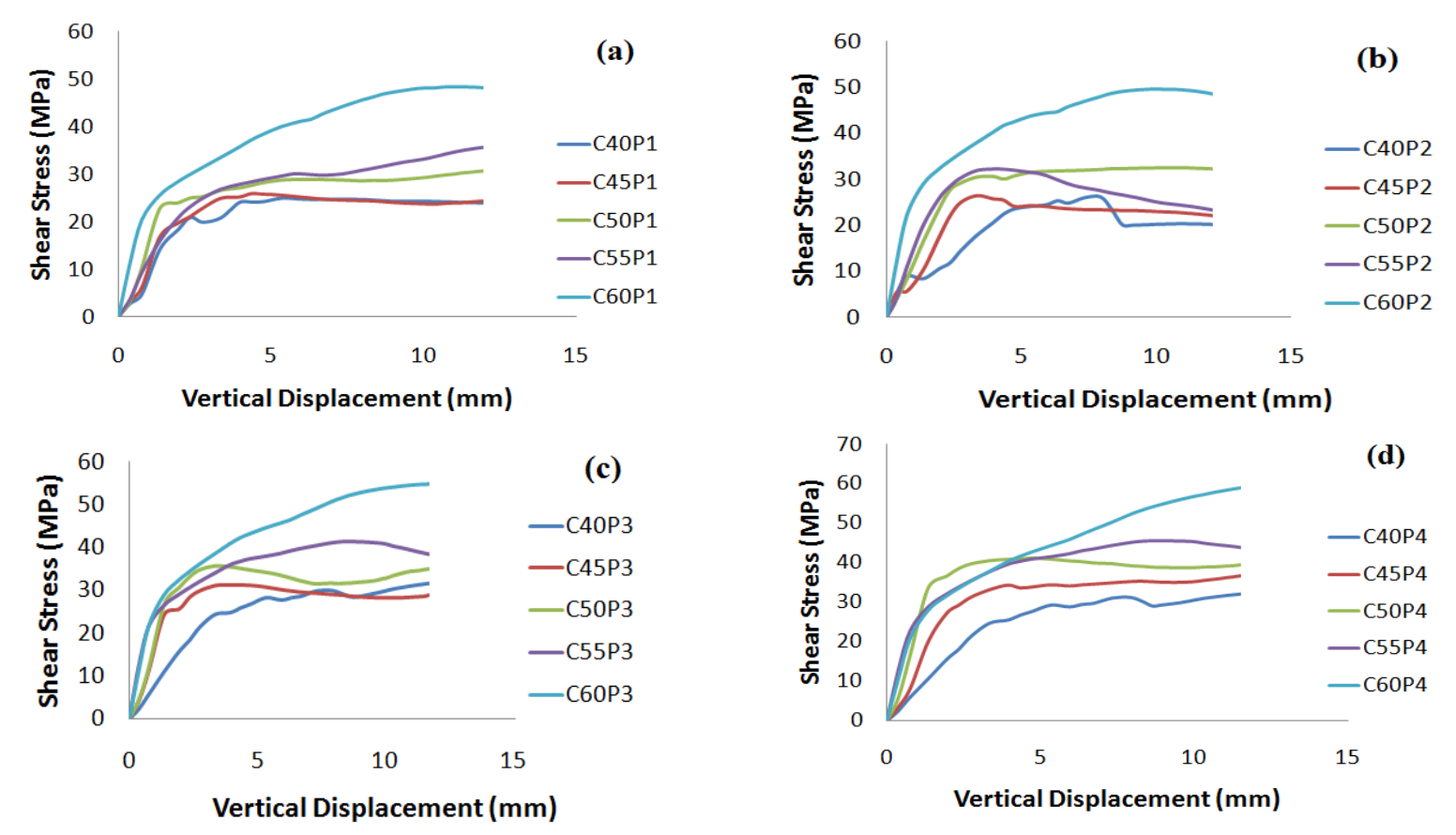

Figure 9 Shear stress-vertical displacement curves as a function of increasing concrete compressive strength with constant prestressing magnitude: (a) P1; (b) P2; (c) P3; (d) P4

The corresponding external vertical forces (in $\mathrm{kN}$ ) that give rise to the initial cracks adjacent to the male shear key are shown in Figure 10. The contours of the same magnitude of external vertical load $(\mathrm{kN})$, when the concrete near to the male shear key sustains initial cracks, are indicated with blue lines. Figure 11 shows the regression equations for the shear stressprestressing relation as a function of different qualities of concrete. Shear stress in Figure 11 is obtained when the first sign of yield occurs at the lower side of the male shear key. Yield beginning at a higher shear stress at the male shear key relates to higher prestressing and will be limited by the yield stress of the shear key material itself. 


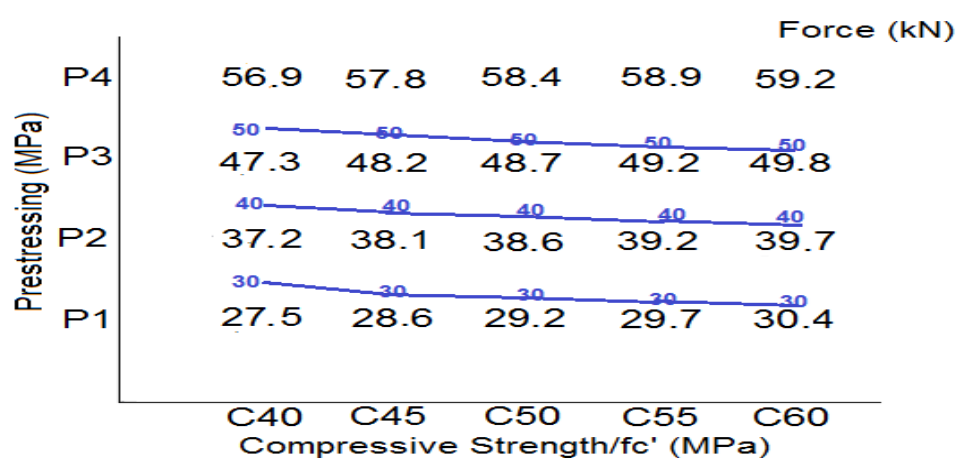

Figure 10 Contours of the same magnitude of external vertical load $(\mathrm{kN})$ when concrete near to the male shear key experiences initial cracks

In order to obtain an idea from the single shear key shear stress when the first sign of yield occurs at the male shear key lower side, a nondimensional contour of same shear stress is made as a function of the nondimensional prestressing magnitude and concrete compressive strength, as presented in Figure 12. In this figure, fy represents the yield stress of FCD 450, $\mathbf{P}$ is the external vertical force working on the surface of the upper-level concrete block, $\mathbf{A}$ is the surface area to which $\mathrm{P}$ is applied, $\mathbf{f c}$ ' is the concrete compressive strength, and $\boldsymbol{\tau}$ is the maximum shear stress at the male shear key when initial yield occurs on the lower side of that shear key. The blue lines are an example of some iso non-dimensional $\boldsymbol{\tau} / \mathbf{0 . 5} \mathbf{f y}$. In view of the shear key design for concrete bridge segmental girders, a more conservative approach would be to use the external vertical load indicator as presented in Figure 10.

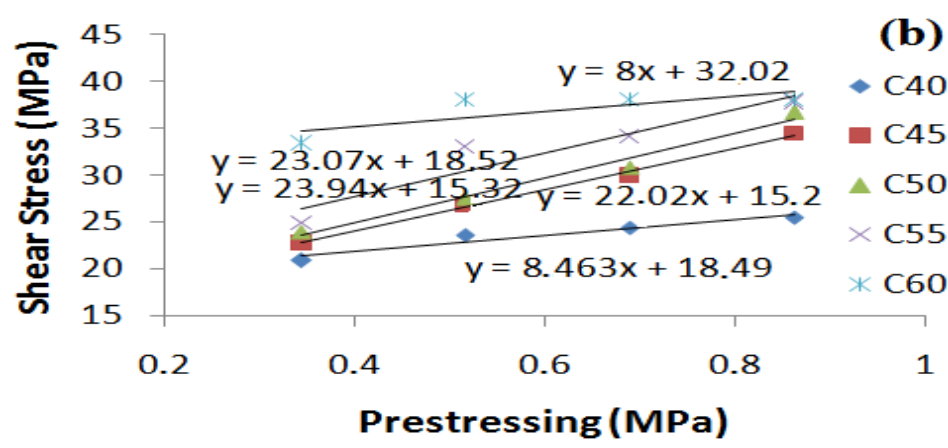

Figure 11 Shear stress-prestressing relation as a function of different qualities of concrete

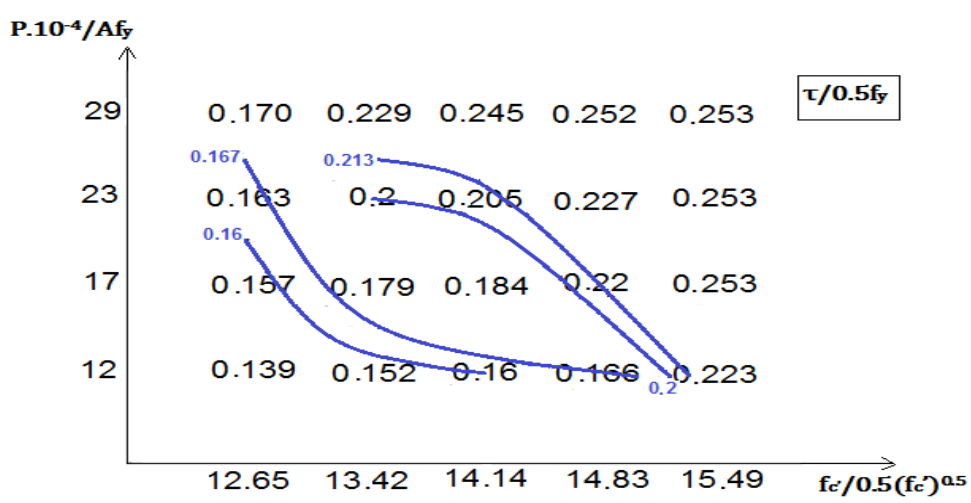

Figure 12 Contours of nondimensional shear stress as a function of concrete quality and normal stress induced by the equivalent prestressing force. 


\section{CONCLUSION}

The numerical studies that have been validated by the two experimental tests show that a shear key made using FCD material can be used for bridge segmental construction. In designing segmental girder joints, the compressive strength of concrete plays an important role as micro cracks start to occur close to the male shear key at a much lower external vertical load compared to the much higher external vertical load that initiates yield at the male shear key. The existence of higher prestressing horizontal force at the upper concrete block decelerates the propagation of cracking in the upper concrete block and the development of yield in the male shear key. A combination of the use of high-quality concrete and higher prestressing force would be safer when designing segmental dry joints using an FCD shear key; however, the interaction between normal force and shear also plays an important role against external vertical force in the event of a failure of the metal shear key.

\section{ACKNOWLEDGEMENT}

The authors would like to express their gratitude to the Government of the Republic of Indonesia for facilitating this research through funding from the 2017 National Strategic Grant. Appreciation also goes to the staff at the Laboratory of Structure and Material, Department of Civil Engineering, Faculty of Engineering, Universitas Indonesia, for their support in the laboratory experimentation.

\section{REFERENCES}

Buyukozturk, O., Bakhoum, M.M., Beattie, S.M., 1990. Shear behavior of Joints in Precast Concrete Segmental Bridges. Journal of Structural Engineering, Volume 116(12), pp. 3380-3401

Dahlberg, C.F.O., Oberg, M., Faleskog, J., 2014. Continuum Modeling of Nodular Cast Iron using a Porous Plastic Model with Pressure-sensitive Matrix- Experiments, Model Calibration \& Verification. Report, School of Engineering Science, KTH Royal Institute of Technology, Stockholm, Sweden

Departemen Pekerjaan Umum, 2004. Perencanaan Struktur Beton Untuk Jembatan. RSNI T12-2004

Dowling, N.E., 2007. Mechanical Behavior of Materials. Pearson Prentice Hall, Upper Saddle River, N.J

Hu, H.-T., Lin, F.-M., Jan, Y.-Y., 2004. Nonlinear Finite Element Analysis of Reinforced Concrete Beams Strengthened by Fiber-reinforced Plastics. Composite Structures, Volume 63(3-4), pp. 271-281

Issa, M.A., Abdalla, H.A., 2007. Structural Behavior of Single Key Joints in Precast Concrete Segmental Bridges. Journal of Bridge Engineering, Volume 12(3), pp. 315-324

Japan Society of Civil Engineers, 2005. Standard Specifications for Concrete Structures-2002Structural Performance Verification. Tokyo, Japan

Kaneko, Y., Mihashi, H., Ishihara, S., 2004. Shear Failure of Plain Concrete in Strain Localized Area. Fracture Mechanics of Concrete Structures, Proceeding of the Fifth International Conference on Fracture Mechanics of Concrete and Concrete Structures, Vail, Colorado, USA

Koseki, K., Breen, J.E., 1983. Exploratory Study of Shear Strength of Joints for Precast Segmental Bridges. FHW/TX-84

Minnebo, P., Nilsson, K.-F., Blagoeva, D., 2007. Tensile, Compression and Fracture Properties of Thick-walled Ductile Cast Iron Components. Journal of Materials Engineering and Performance, Volume 16(1), pp. 35-45 
Post Tensioning Institute PTI, 1978. Precast Segmental Box Girder Bridge Manual. Glenview, Illinois

Reddiar, M.K.M., 2009. Stress-strain Model of Unconfined and Confined Concrete and Stressblock Parameters. Diss. Texas A\&M University

Rifai, A.I., Hadiwardoyo, S.P., Correia, A.G., Pereira, P., Cortez, P., 2015. The Data Mining Applied for the Prediction of Highway Roughness due to Overloaded Trucks. International Journal of Technology, Volume 6(5), pp. 751-761

Yang, I.-H., Kim, K.-C, Kim, Y.-J., 2013. Shear Strength of Dry Joints in Precast Concrete Modules. In: Proceeding of EASEC13

Zhou, X., Mickleborough, N., Li, Z., 2005. Shear Strength of Joints in Precast Concrete Segmental Bridges. ACI Structural Journal, Volume 102(1), pp. 3-11 